\title{
Short-term feeding response of the mussel Mytilus chilensis exposed to diets containing the toxic dinoflagellate Alexandrium catenella
}

\author{
Respuesta alimentaria inicial del bivalvo Mytilus chilensis expuesto a dietas conteniendo el \\ dinoflagelado tóxico Alexandrium catenella
}

JORGE M. NAVARRO*, ANDREA M. CONTRERAS ${ }^{1} \&$ ÓSCAR R. CHAPARRO

\begin{abstract}
Instituto de Biología Marina "Dr. Jürgen Winter", Universidad Austral de Chile, Casilla 567, Valdivia, Chile
${ }^{1}$ Present address: School of Biological Sciences, University of Canterbury, Private Bag 4800, Christchurch, New Zealand; *e-mail for correspondence: jnavarro@uach.cl
\end{abstract}

\begin{abstract}
The short-term feeding response of the bivalve Mytilus chilensis was measured using four diets containing different proportions of the toxic dinoflagellate Alexandrium catenella. The diets containing the highest concentrations of the dinoflagellate showed the greatest effect on the feeding activity in the mussel, with clearance and ingestion rates significantly reduced during the first hours of exposure. After this period, $M$. chilensis demonstrated a capacity to acclimate to the toxic diets, with feeding parameters reaching values similar to those of untreated control organisms. It was not clear if the negative effect on the feeding behavior was caused by the presence of the paralytic toxin, or due to the larger size of the dinoflagellate cells in comparison with cells of Isochrysis galbana used in the control diet. However, parallel studies with diets containing the nontoxic dinoflagellate Alexandrium affine of similar size and shape to that of A. catenella, suggested the cell size was the main cause for impairment of feeding behavior. The capacity for acclimation to either toxin or cell size by M. chilensis makes it a good indicator species for the early detection of harmful PSP events, since its relative insensitivity to the toxin allows it to quickly recover normal feeding behavior and permits it to accumulate PSP in its tissues in a short time.
\end{abstract}

Key words: Mytilus chilensis, feeding response, PSP, dinoflagellates.

\section{RESUMEN}

La respuesta inicial del bivalvo Mytilus chilensis fue medida bajo cuatro dietas que contenían diferentes proporciones del dinoflagelado tóxico Alexandrium catenella. Las dietas que contenían las concentraciones más altas de este dinoflagelado mostraron el mayor efecto durante las primeras horas de exposición. Después de este periodo inicial, $M$. chilensis demostró la capacidad para aclimatarse a estas dietas tóxicas, con parámetros de alimentación que alcanzaron valores similares a aquellos de los organismos controles. No fue claro si el efecto negativo sobre la conducta de alimentación fue causado por la presencia de la toxina paralizante o debido al gran tamaño de las células del dinoflagelado, en comparación al tamaño de las células de Isochrysis galbana usadas en la dieta control. Sin embargo, estudios paralelos con dietas conteniendo el dinoflagelado no tóxico Alexandrium affine, de similar tamaño y forma a A. catenella, sugieren que el tamaño de las células fue la causa principal que afectó la conducta de alimentación. La capacidad de aclimatación ya sea a la toxina o al tamaño celular del dinoflagelado, identifica a $M$. chilensis como una buena especie para la detección temprana de eventos tóxicos producidos por A. catenella, ya que debido a su relativa insensibilidad a la toxina permite una rápida recuperación de su conducta de alimentación y la acumulación de toxina en sus tejidos.

Palabras clave: Mytilus chilensis, respuesta de alimentación, toxina paralizante, dinoflagelados.

\section{INTRODUCTION}

The presence of paralytic shellfish poisoning (PSP) produced by dinoflagellate species in the natural environment has been described as a factor causing a variety of sub lethal effects in marine bivalves. Symptoms identified include closure of the valves, reduction in filtration activity, drops in metabolic rates, increase in mucus production, and erratic cardiac activity (Shumway et al. 1985). One of the most common effects during exposure to paralytic 
toxin is isolation from the immediate environment by firm closure of the valves which implies cessation of filtering activity. Thus for example when Mytilus edulis was exposed to the toxic dinoflagellate Protogonyaulax tamarense, it demonstrated erratic closure of the valves, while Mercenaria mercenaria showed complete closure of the valves (Gainey \& Shumway 1988). Reduction of filtering activity due to valve or siphon closure has also been reported for M. edulis and Mya arenaria (Shumway \& Cucci 1987), M. mercenaria (Dupuy \& Sparks 1968) and Crassostrea virginica (Ray \& Aldrich 1967, Shumway \& Cucci 1987). Wildish et al. (1998) studying the effects of toxic and non-toxic strains of Alexandrium tamarense on the initial feeding response of the oyster Crassostrea gigas found a start/stop feeding behaviour with both strains of the dinoflagellate, in contrast with oysters fed with the Isochrysis sp. used as a reference species and with which the oysters did not exhibit this behaviour.

Chile has large populations of filter feeding bivalve species inhabiting its southern regions which are susceptible to contamination by toxins produced by blooms of A. catenella. During the last decade, these harmful algae blooms (HABs) have increased in frequency, intensity, and area affected including the coastal zone from Castro $\left(42^{\circ} 29^{\prime} \mathrm{S}, 73^{\circ} 48^{\prime} \mathrm{W}\right.$, Chiloé Island) to south of the Beagle Channel $\left(55^{\circ} 07^{\prime} \mathrm{S}, 68^{\circ} 36^{\prime} \mathrm{W}\right)$. From 1991 to the present, several cases of red tides formed by $A$. catenella occurred in southern Chile, with the largest in the summer-fall of 2002 having maximum concentrations of $7.8 \times 10^{5}$ cells $\mathrm{L}^{-1}$ (Clement et al. 2002) ${ }^{1}$ and toxicity values of above $8500 \mu \mathrm{g}$ of STX/100 g bivalve tissue. It is therefore relevant to evaluate the effect of diets containing PSP-producing dinoflagellates on key species from the ecosystems of southern Chile, as is the case of Mytilus chilensis. Shortterm studies of physiological responses in the mussels to the presence of PSP may be able to identify the potential of using them as an indicator species for red tide events in the region. Considering the preceding, the present

CLEMENT A, A AGUILERA \& C FUENTES (2002) Análisis de marea roja en Archipiélago de Chiloé, contingencia verano 2002. XXII Congreso de Ciencias del Mar, 28-30 de mayo, Valdivia, Chile. study was carried out under controlled conditions to determine the effects of diets containing different concentrations of $A$. catenella on the filtration activity and the subsequent level of toxicity acquired by $M$. chilensis.

\section{MATERIAL AND METHODS}

\section{Collection site and experimental mussels}

Adult individuals of $M$. chilensis were collected in August 2004, from culture ropes at the Yaldad Experimental Station in southern Chile $\left(43^{\circ} 08^{\prime} \mathrm{S}, 73^{\circ} 44^{\prime} \mathrm{W}\right)$. Individuals of about the same lengths were chosen $(5.38 \pm$ $0.16 \mathrm{~cm}$ ), having dry tissue weights of about $0.75 \pm 0.20 \mathrm{~g}$ (termed "standard size" in the present study). The mussels were transported to the laboratory, where they were acclimated in four tanks of $20 \mathrm{~L}$ volume $(25$ mussels per tank) for one week at a temperature of $14{ }^{\circ} \mathrm{C}$ and seawater salinity of $30 \%$. During this period they were fed "ad libitum" with the microalga Isochrysis galbana and provided with constant aeration from compressed air bubblers. Seawater was changed every $48 \mathrm{~h}$.

\section{Preparation of diets}

Monoclonal non-axenic Alexandrium catenella (strain ACC02) was employed as food in a series of feeding experiments. This strain was isolated in Chile's Aysen Region in 1994 and was kindly donated by the Centro Regional de Análisis de Recursos y Medio Ambiente (CERAM) of the Universidad Austral de Chile. Alexandrium catenella was cultivated in 0.45 um filtered seawater enriched with "L1" algae culture medium (Guillard 1995), at $14{ }^{\circ} \mathrm{C}$ and $30 \%$ S. Isochrysis galbana was cultivated using $f / 2$ medium (Guillard 1975). The experiments were carried out using both species of algae harvested in their exponential growth phase.

To emulate the organic fraction of the natural suspended particulate matter, sediment was used for preparation of the diets. It was collected from the upper centimeter of the substrate on the Yaldad tidal flat, sieved to $40 \mu \mathrm{m}$, rinsed with distilled water, and ashed in a muffle furnace at $500{ }^{\circ} \mathrm{C}$ for $12 \mathrm{~h}$ to eliminate the organic fraction. 
After ashing, the sediment was again sieved to eliminate sediment aggregations.

Experimental diets $\left(1.7-2.0 \mathrm{mg} \cdot \mathrm{L}^{-1}\right.$; dry weight) were prepared, with different dry weight proportions of A. catenella, I. galbana and sediment, in order to provide a range of diets containing different levels of toxicity as listed in Table 1. The control diets were prepared by mixing I. galbana with sediment or with pure I. galbana. The experiments were carried out consecutively with each diet, each time using seven $15 \mathrm{~L}$. experimental aquaria containing numbers of mussels in accordance with the duration of each experiment (two mussels per measurement). Four aquaria contained mussels fed with the diet containing A. catenella, and the other three with mussels fed the control diet. Each day each aquarium received an amount of food representing $3 \%$ $\left(23 \mathrm{mg}\right.$ day $\left.^{-1}\right)$ of the dry body weight of the experimental mussels, delivered continuously using a Masterflex 7519-05 peristaltic pump at the temperature and salinity cited above. The concentration of saxitoxin in each diet was calculated on the basis of the results of Navarro et al. (2006), who found a mean concentration of $3.84 \pm 1.81 \mathrm{fmole}$ cell $^{-1}$ in the same strain of A. catenella (ACC02) and under the same culture conditions.

\section{Toxin analyses in soft tissues}

The toxin content in the soft tissues of $M$. chilensis was calculated by pooling the tissues of two individuals (5 $\mathrm{g}$ approx.) from each experimental aquarium on days $0,1,2$, and 3 of the experiment. The same procedure was carried out on individuals from control aquariums to verify complete absence of toxin. Toxin content of the tissues was quantified using the electrophysiological test of Vélez et al. (2001), where HEK 293 cells (human embryonic kidney cells) expressing STX-sensitive rat skeletal muscle $\mathrm{Na}$ channels were patch clamped in the whole-cell configuration. The equivalent STX concentration was estimated using calibration curves obtained by external perfusion with known concentrations of purified STX; these curves were generated using a stepped series of increasing concentrations of STX-dihydrochloride (US Food and Drug Administration, Office of Seafood). According to Velez et al. (2001), there is a correlation of 0.96 between the mouse bioassay and the electro-physiological test.

\section{Clearance rate}

The clearance rate (CR) was estimated using mussels from the seven experimental aquaria twice a day, until the test mussel showed a feeding response which did not differ to the test mussels, over periods of $0,6,2430,48,54$, and $72 \mathrm{~h}$. The clearance rate was determined with the four experimental diets, using a particle concentration that varied between 1.7 and 2.0 $\mathrm{mg} \mathrm{L}^{-1}$ dry weight, temperature of $14^{\circ} \mathrm{C}$ and salinity of $30 \%$. The clearance rate experiments were carried out in a static system that was homogenized by aeration, in which the decrease in particle concentration was periodically monitored in each experimental aquarium. This was carried out using an Elzone

TABLE 1

Composition of the experimental and control diets utilized in the feeding experiments with Mytilus chilensis

Composición de las dietas experimentales y control utilizadas en los experimentos de alimentación con Mytilus chilensis

\begin{tabular}{|c|c|c|c|c|c|c|c|}
\hline Diet condition & $\begin{array}{l}\text { Total diet } \\
\left(\mathrm{mg} \mathrm{d}^{-1}\right)\end{array}$ & $\begin{array}{c}\text { Organic } \\
\text { matter }\left(\mathrm{mg} \mathrm{d}^{-1}\right)\end{array}$ & $\begin{array}{l}\text { A. catenella } \\
\left(\mathrm{mg} \mathrm{d}^{-1}\right)\end{array}$ & $\begin{array}{l}\text { I. galbana } \\
\left(\mathrm{mg} \mathrm{d}^{-1}\right)\end{array}$ & $\begin{array}{l}\text { Sediment } \\
\left(\mathrm{mg} \mathrm{d}^{-1}\right)\end{array}$ & $\begin{array}{l}\text { A. catenella } \\
\left(\text { cells d}^{-1}\right)\end{array}$ & $\begin{array}{l}\text { Toxicity } \\
\left(\mathrm{pmol} \mathrm{d}^{-1}\right)\end{array}$ \\
\hline Diet 1 (10\% A. catenella) & 23 & $9.5(41.4 \%)$ & 2.3 & 6.9 & 13.8 & 489,362 & 1,879 \\
\hline Diet $2(30 \%$ A. catenella $)$ & 23 & $8.3(36.3 \%)$ & 6.9 & 2.3 & 13.8 & $1,468,085$ & 5,637 \\
\hline Diet 3 (50\% A. catenella) & 23 & $12.4(54.0 \%)$ & 11.5 & 2.3 & 9.2 & $2,446,809$ & 9,396 \\
\hline Diet 4 (100\% A. catenella & 23 & $20.5(89.0 \%)$ & 23.0 & 0.0 & 0.0 & $4,893,617$ & 18,792 \\
\hline $\begin{array}{l}\text { Control (Diets 1-2-3) } \\
(47.0 \% \text { I. galbana) }\end{array}$ & 23 & $10.3(44.7 \%)$ & 0.0 & 10.8 & 12.2 & 0.0 & 0.0 \\
\hline $\begin{array}{l}\text { Control (Diet 4) } \\
(100 \% \text { I. galbana })\end{array}$ & 23 & $20.9(90.7 \%)$ & 0.0 & 23 & 0.0 & 0.0 & 0.0 \\
\hline
\end{tabular}


model 180XY particle counter equipped with a counting tube having a $120 \mu \mathrm{m}$ aperture. These tests were carried out over a period of three hours, with measurements made every 30 minutes, and in every case replacing the food consumed with new food. To test any sedimentation of the cells during the feeding measurements, a control aquarium without the presence of mussels was run. The clearance rate $(\mathrm{L} / \mathrm{h})$ was calculated following Coughlan (1969).

\section{Ingestion rate}

A known volume of each experimental diet (in triplicate) was concentrated on $47 \mathrm{~mm}$ diameter Whatman GF/C glass fiber filters, which had been previously washed, ashed and tared. Blank filters as well as filters with retained diets were rinsed with isotonic ammonium formate to remove salt and prevent cell lysis. The filters were dried at $80{ }^{\circ} \mathrm{C}$ for $24 \mathrm{~h}$, weighed, ashed at $450{ }^{\circ} \mathrm{C}$ for $3 \mathrm{~h}$ and reweighed after cooling in a desiccator, to calculate total and organic content of the diets. The concentration of food used (1.7-2.0 $\mathrm{mg} \mathrm{L}^{-1}$ ) was below the threshold of pseudofeces production (Velasco \& Navarro 2002) so that the ingestion rate could be calculated as the product of the clearance rate and the amount of material contained in each experimental diet.

\section{Statistical analyses}

The response of $M$. chilensis to the experimental diets was analyzed using STATISTICA 4.2 software. The means were compared using one way analysis of variance (ANOVA), followed by a "post-hoc" Tukey test, using a $\log (\mathrm{x})$ transformation of the data when these did not comply with a posteriori assumptions (normality and homogeneity of the variance). The relation between clearance rate and A. catenella cell concentration was carried out using regression analysis.

\section{RESULTS}

The M. chilensis in the control group showed a clearance rate (CR) which was stable over time. The mussels of the toxin-contaminated group demonstrated erratic behavior (Fig. 1A) when given the diet containing the lowest proportion of A. catenella (10\%). More stable behavior was observed in mussels exposed to diets containing 30 and $50 \%$ A. catenella. In these, an initial feeding reduction on the diet containing the toxic dinoflagellate was observed (Fig. 1B and 1C), followed by a period of acclimation to the diet, and then reaching the values of the controls. With the diet consisting only of $A$. catenella, the $M$. chilensis clearance rate became significantly lower $(\mathrm{P}<0.05)$ than the controls during the first $54 \mathrm{~h}$. The mussels acclimated to this diet by $72 \mathrm{~h}$, again reached the rate of the control group (Fig. 1D). Thus the effect of A. catenella on lowering the feeding rate of $M$. chilensis was more intense and more extended in time as the proportion of A. catenella increased in the diet, which represented an inverse relation between the capacity of $M$. chilensis to acclimate, and the concentration of A. catenella in the diet. The highest average clearance rate was observed in the control mussels (hour 0) fed with (nontoxic) diet 4, with an average of $3.93 \mathrm{~L} \mathrm{~h}^{-1}$. The lowest average clearance rate, $0.31 \mathrm{~L} \mathrm{~h}^{-1}$, was observed in experimental individuals fed (toxic) diet 4 at the beginning of the experiment (hour 0).

The relationship between clearance rate and the number of cells of $A$. catenella supplied in the diets (Fig. 2A and 2B), indicated a significant negative correlation $(\mathrm{P}<0.05)$ at hours 0 and $24\left(\mathrm{R}^{2}=0.75\right.$ and 0.96 , respectively). In the sampling at $54 \mathrm{~h}$. there was no significant relationship $(\mathrm{P}>0.05)$ between these variables (Fig. 2C). Variation in ingestion rate (IR) follows exactly the same trends as those described previously for clearance rate (CR).

The toxic content in the tissues of the individuals fed during $72 \mathrm{~h}$ with diets 1 and 2 were not significantly different from each other, and remained below the safety limit for human consumption (80 $\mu \mathrm{g}$ STX eq $100 \mathrm{~g}^{\text {tissue }}{ }^{-1}$ ). In contrast, the mussels fed with diets 3 and 4 reached toxin levels significantly higher than with the other two diets, and showed values above the safety limit for human consumption (diet $3=236.8 \mu \mathrm{g}$ STX eq $100 \mathrm{~g}$ tissue $^{-1}$; diet $4=$ $314.5 \mu \mathrm{g}$ STX eq $100 \mathrm{~g}_{\text {tissue }}{ }^{-1}$ ), with values significantly different than those obtained with diets 1 and 2 , but not significantly different between each other (Fig. 3). 

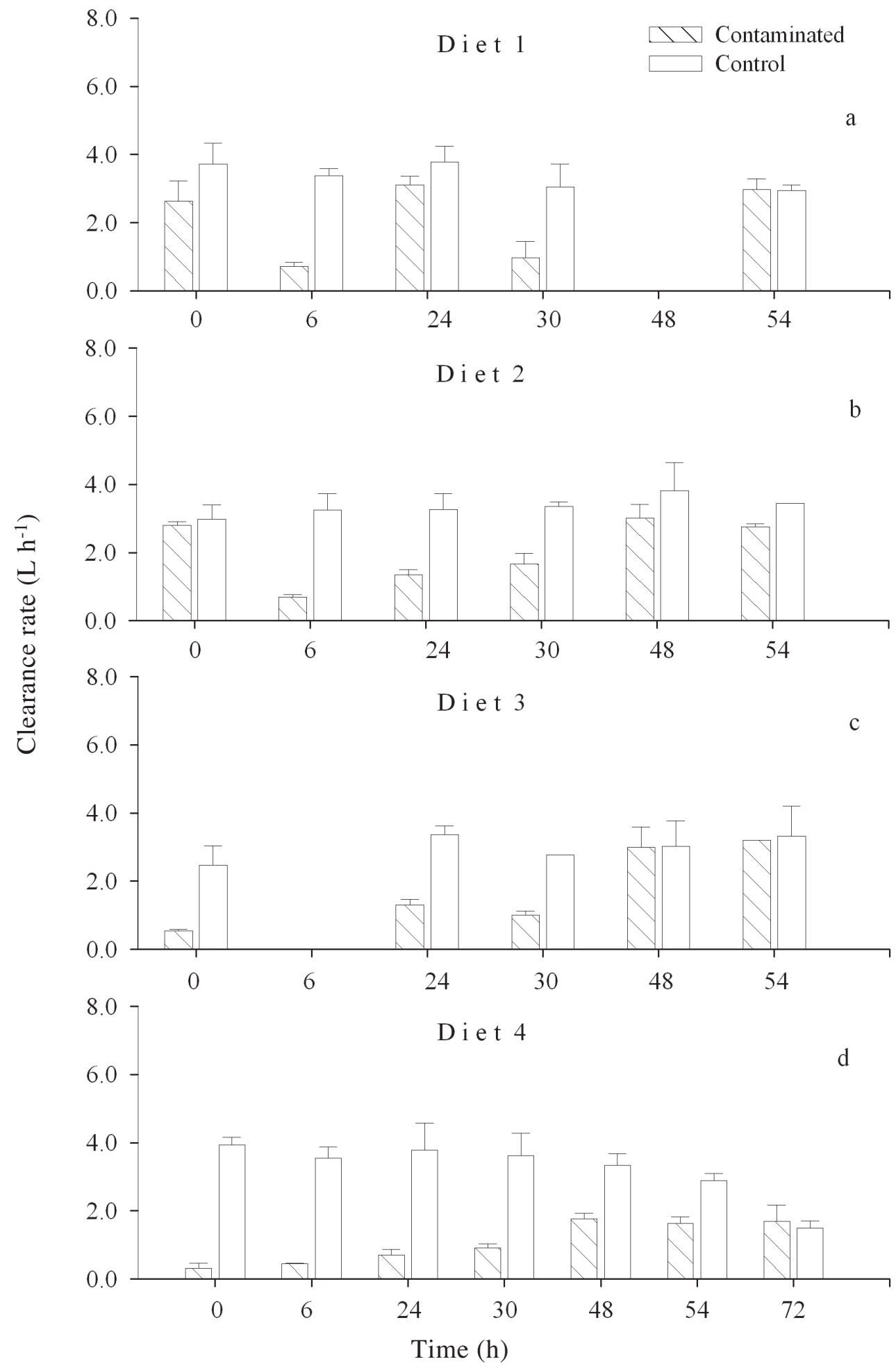

Fig.1: Clearance rate of M. chilensis (standard animal) fed with diets containing different concentrations of $A$. catenella (see Table 1 for diet composition). Values are means \pm standard error.

Tasa de aclaramiento de Mytilus chilensis (animal estándar) alimentado con dietas conteniendo diferentes concentraciones de A. catenella (ver Tabla 1 para composición de las dietas). Valores corresponden a medias \pm error estándar. 

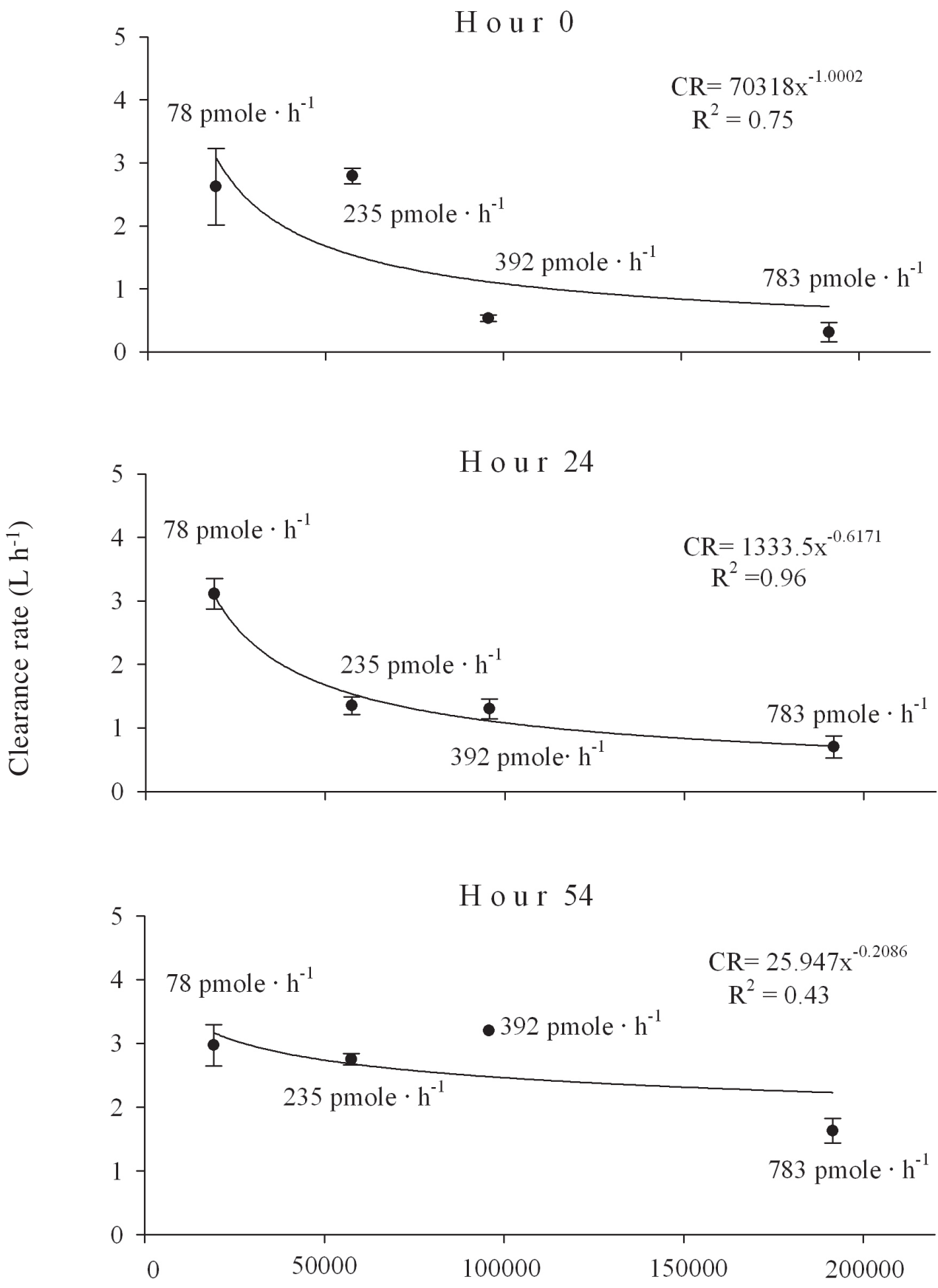

\section{A. catenella $\left(\right.$ cells h$\left.^{-1}\right)$}

Fig. 2: Clearance rate of M. chilensis (standard animal) in relation to cell number of A. catenella supplied in the diets. Values are means \pm standard error.

Tasa de aclaramiento de $M$. chilensis (animal estándar) en relación al número de células de A. catenella entregado en las dietas. Valores corresponden a medias \pm error estándar. 


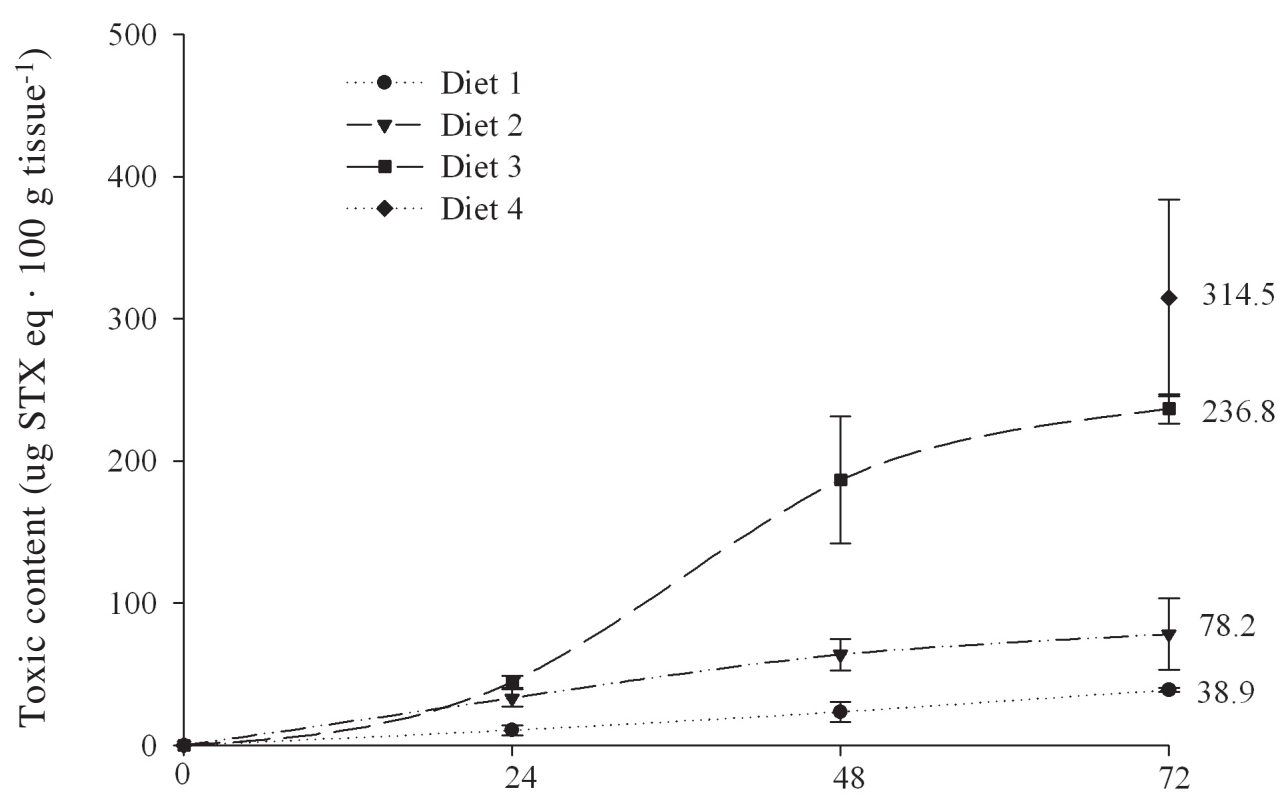

Time (h)

Fig. 3: STX equivalent of M. chilensis (standard animal) exposed to diets containing different concentrations of A. catenella. For diet 4 (days 1 and 2) there is no information. Values are means \pm standard error.

STX equivalente en $M$. chilensis (animal estándar) expuesto a dietas conteniendo diferentes concentraciones de $A$. catenella. Para dieta 4 (días 1 y 2) no existe información. Valores corresponden a medias \pm error estándar.

\section{DISCUSSION}

The genus Mytilus has been described as generally insensitive to dinoflagellates containing paralytic shellfish toxin (Bricelj \& Shumway 1998), experiencing only a small reduction in their filtering rates although high levels of toxins accumulate in their tissues during short periods of exposure. Contrasting behavior has been described for other filter feeding bivalves such as the oyster Crassostrea gigas (Bardouil et al. 1993) and the clam Mya arenaria (Bricelj et al. 2005). Filtration activity of these species is sensitive to PSP toxins; hence they do not accumulate high concentrations of toxins, presumably due to behavioral and physiological mechanisms used to avoid exposure to the toxic dinoflagellate cells (Gainey \& Shumway 1988).

Similarly to the results obtained with diet 1 for M. chilensis, Li et al. (2001, 2002) observed no negative effects of diets containing small amounts of paralytic toxin on clearance rates of the mussel Perna viridis. Bardouil et al. (1996) showed that the inclusion of $10 \%$ toxic A. tamarense in a diet produced a $20 \%$ reduction in the clearance rate of Crassostrea gigas. The initial negative effect of our diets 2, 3 and 4 on the clearance and ingestion rates of $M$. chilensis, was similar to the behavior described by Wildish et al. (1998). These authors described a start/stop behavior in the clearance rate of the oyster $C$. gigas when fed toxic and nontoxic strains of Alexandrium tamarense, suggesting that periods of over $48 \mathrm{~h}$ were required to achieve acclimation to these diets. Bardouil et al. (1996) demonstrated a complete inhibition of filtering activity in C. gigas in the first six hours of experimentation when using a diet composed solely of toxic A.tamarense. Dupuy $\&$ Sparks (1968) mentioned that a period of two weeks was required for $C$. gigas to return to normal feeding on $A$. catenella which was greater than the time observed in the present study with the mussel M. chilensis. This supports the contention that the mytilids have a high capacity for acclimation to diets containing toxic dinoflagellates (Lesser \& Shumway 1993, Bricelj \& Shumway 1998). 
A number of authors have related the reduction of filtration activity to the sensitivity of bivalves to the paralytic toxin (Twarog \& Yamaguchi 1974, Shumway \& Cucci 1987). The capacity of acclimation in $M$. chilensis may also be related to the origin of the population studied (Yaldad Bay, Chiloé), which was exposed in 2002 to one of the largest blooms of A. catenella ever occurring in Chile, when concentrations reached $7.8 \times 10^{5}$ cells L-1 (Clement et al. 2002), accompanied by toxin levels of $8554 \mathrm{ug}$ STX eq $100 \mathrm{~g}$ M. chilensis tissue $^{-1}$ (Llanchipal Health Service). Twarog et al. (1972) compared resistance to STX of various bivalve species, measuring the blocking of action potentials of the sodium channels on a cellular level. These authors concluded that Mytilus edulis was the most resistant species to the toxin, noting that previous exposure of the individuals to toxic algal blooms was related to differences in the responses measured. An example of this was the study by Shumway \& Cucci (1987) who suggested that individuals of $M$. edulis from areas which had never experienced toxic blooms were more sensitive to PSP than individuals originating in areas which undergone repeated toxic algal blooms. These results coincide with those described by Bricelj et al. (2005), where individuals of the clam Mya arenaria exposed to recurrent toxic events experienced a natural mutation of an amino acid which prevented the union of the saxitoxin with the pore of the sodium channel, thus permitting normal conduction of nervous impulses of the cells and conferring greater resistance to the toxin in these individuals. Nevertheless, in the case of $M$. chilensis this behavior seems to be more related to the effect on the feeding mechanism of the bivalve in relation to the larger size of the dinoflagellate cell in comparison with that of feeding on Isochrysis (A. catenella $=32-36 \mu \mathrm{m}, I$. galbana $=4-5 \mu \mathrm{m})$ than to the toxicity of the dinoflagellate. Indeed, preliminary results of a parallel study carried out to evaluate the capacity for pre-ingestive selection by $M$. chilensis exposed to a mixed diet (1:1 by weight) of I. galbana and the non-toxic dinoflagellate Alexandrium affine (which has a similar size and shape to A. catenella) also showed a significant initial reduction in the clearance rate compared to controls only fed with Isochrysis. This response of M. chilensis could be also related with the stimuli produced by chemical cues from the dinoflagellate species, as has been suggested by Wildish et al. (1998), who concluded that PSP was not the cause of the initial inhibition of the feeding response since both toxic and nontoxic strains of A.tamarense caused start/stop feeding in the oyster $C$. gigas.

This insensitivity of $M$. chilensis to PSP allows it to accumulate toxin in its tissues in a short period of time, suggesting it would be valuable as an indicator species for early detection of harmful algal blooms. The increasing frequency of blooms of A. catenella in southern Chile make it essential to continue studies which help define the responses of $M$. chilensis to these blooms in the long term. This is of importance considering the ecological relevance of the species as well as its commercial export value based on the high volume of these mussels produced in artificial cultures which are undergoing continued expansion in southern Chile.

\section{ACKNOWLEDGEMENTS}

We especially thank G. Urrutia and $M$ Maturana for their valuable help during the experiments, to M. Seguel for providing the $A$. catenella strain (ACC02). We also thank Marco Cordova from the laboratory of Marine Toxins from Universidad de Chile for performing electro-physiological analysis of Alexandrium catenella cells. This study was supported by a research grant to JMN (FONDECYT 1030340).

\section{LITERATURE CITED}

BARDOUIL M, M BOHEC, M CORMERAIS, S BOUGRIER \& P LASSUS (1993) Experimental study of the effects of a toxic microalgae diet on feeding of the oyster Crassostrea gigas (Thunberg). Journal Shellfish Research 12: 417-422.

BARDOUIL M, M BOHEC, S BOUGRIER, P LASSUS \& P TRUQUET (1996) Feeding Responses of Crassostrea gigas (Thunberg) to inclusion of different proportions of toxic dinoflagellates in their diets. Oceanologica Acta 19: 177-182.

BRICELJ VM \& SE SHUMWAY (1998) Paralytic shellfish toxins in bivalve molluscs: occurrence, transfer kinetics, and biotransformation. Reviews in Fisheries Science 6: 315-383.

BRICELJ VM, L CONNELL, K KONOKI, SP MACQUARRIE, T SCHEUER, WA CATTERALL \& VL TRAINER (2005) Sodium channel mutation 
leading to saxitoxin resistance in clams increases risk of PSP. Nature 434: 763-767.

COUGHLAN J (1969) The estimation of filtering rate from the clearance of suspensions. Marine Biology 2: $356-358$

DUPUY JL \& AK SPARKS (1968) Gonyaulax washingtonensis, its relationship to Mytilus californianus and Crassostrea gigas as a source of paralytic shellfish toxin in Sequien Bay, Washington. Proceedings of the National Shellfish Association 58: 2.

GAINEY LF \& SE SHUMWAY (1988) A compendium of the responses of bivalve molluscs to toxic dinoflagellates. Journal Shellfish Research 7: 626628 .

GUILLARD RRL (1975) Culture of phytoplankton for feeding marine invertebrates. In: Smith WL \& MH Chanley (eds) Culture of marine invertebrate animals: 29-60. Plenum Press, New York, New York, USA.

GUILLARD RRL (1995) Culture methods. In: Hallegraeff GM, DM Anderson \& AD Cembella (eds) Manual on harmful marine microalgae. IOC Manuals and Guides No. 33: 45-62. UNESCO, Paris, France.

LESSER MP \& SE SHUMWAY (1993) Effects of toxic dinoflagellates on clearance rates and survival in juvenile bivalve molluscs. Journal Shellfish Research 12: 377-381

LI SC, WX WANG \& DPF HSIEH (2001) Feeding and absorption of the toxic dinoflagellate Alexandrium tamarense by two marine bivalves from the South China Sea. Marine Biology 139: 617-624.

LI SC, WX WANG \& DPF HSIEH (2002) Effects of toxic dinoflagellate Alexandrium tamarense on the energy budgets and growth of two marine bivalves. Marine Environmental Research 53: 145-160.

NAVARRO JM, M MUÑOZ \& AM CONTRERAS (2006) Temperature as a factor regulating growth and toxin content in the dinoflagellate Alexandrium catenella. Harmful Algae 5: 762-769.

Associate Editor: Francisco Bozinovic

Received June 25, 2007; accepted August 13, 2007
RAY SM \& DV ALDRICH (1967) Ecological interactions of toxic dinoflagellates and Molluscs in the Gulf of Mexico. In: Russel FE \& RP Saunders (eds) Animal toxin: 75-83. Pergamon Press, New York, New York, USA.

SHUMWAY SE, TL CUCCI, RC NEWELL \& CM YENTSCH (1985) Particle selection, ingestion, and absorption in filter-feeding bivalves. Journal Experimental Marine Biology and Ecology 91: 7792.

SHUMWAY SE \& TL CUCCI (1987) The effects of the toxic dinoflagellate Protogonyaulax tamarensis on the feeding and behaviour of bivalve molluscs. Aquatic Toxicology 10: 9-27.

TWAROG BM, T HIDAKA \& H YAMAGUCHI (1972) Resistence to tetrodotoxin and saxitoxin in nerves of bivalve mollusk. Toxicon 10: 273-278.

TWAROG BM \& H YAMAGUCHI (1974) Resistance to paralytic shellfish toxins in bivalve molluscs. In: Lo Cicero VR (ed) Proceeding of the First International Conference on Toxic Dinoflagellate Blooms: 382393. Boston, Massachusetts Science and Technology Foundation. Wakefield, Massachusetts, USA.

VELASCO LA \& JM NAVARRO (2002) Feeding physiology of infaunal (Mulinia edulis) and epifaunal (Mytilus chilensis) bivalves under a wide range of concentration and quality of seston. Marine Ecology Progress Series 240: 143-155.

VÉLEZ P, J SIERRALTA, C ALCAYAGA, M FONSECA, H LOYOLA, DC JOHNS, GF TOMASELLI \& BA SUÁREZ-ISLA (2001) A functional assay for paralytic shellfish toxins that uses recombinant sodium channels. Toxicon 39: 929-935.

WILDISH D, P LASSUS, J MARTIN, A SAULNIER \& M BARDOUIL (1998) Effect of the PSP-causing dinoflagellate, Alexandrium sp., on the initial feeding response of Crassostrea gigas. Aquatic Living Resources 11: 35-43. 
